\title{
TINDAK TUTUR PERFOMATIF PADA BUKU AUTOBIOGRAFI RENTANG KISAH KARYA GITA SAVITRI DEVI
}

\author{
Tiara Urbaningrum ${ }^{* 1}$, Leli Triana ${ }^{2}$, Vita Ika Sari ${ }^{3}$ \\ ${ }^{*}{ }_{1,2,3}$ Prodi Pendidikan Bahasa dan Sastra Indonesia, Fakultas Keguruan dan Ilmu Pendidikan Universitas \\ Pancasakti Tegal, Indonesia \\ e-mail: tiaraurbaningrum99@gamil.com, lelitriana99@gmail.com,vitaidea859799@gmail.com
}

\begin{abstract}
ABSTRAK
Tuturan adalah hal yang sangat penting dalam berkomunikasi, hal ini dapat dilihat dalam banyak aspek kehidupan bahwa manusia adalah makhluk sosial yang tidak dapat hidup tanpa berkomunikasi satu sama lain. Penggunaan tuturan sangat berpengaruh pada mitra tutur, hal ini dapat dilihat dari bagaimana respon mitra tutur kepada penutur. Penelitian ini mengkaji tindak tutur performatif Gita Savitri Devi dalam buku Rentang Kisah yang bertujuan untuk mendeskripsikan bentuk tindak tutur performatif dalam buku tersebut. Penelitian ini menggunakan pendekatan deskriptif kualitatif. Sumber data penelitian ini berasal dari tuturan Gita Savitri dalam buku Rentang Kisah. Teknik pengumpulan data menggunakan teknik simak bebas libat cakap dengan teknik lanjutan teknik catat. Analisis data menggunakan metode korelasi dengan penyajian hasil analisis menggunakan metode informal. Hasil penelitian menunjukkan 82 tuturan performatif yang diklasifikasikan menjadi lima, yaitu representatif terdapat 44 data, direktif terdapat 8 data, ekspresif terdapat 26 data, komisif terdapat 1 data dan deklaratif terdapat 3 data.
\end{abstract}

Kata Kunci : Tindak tutur performatif, rentang kisah.

\begin{abstract}
Speech is very important in communication, it can be seen in many aspects of life that humans are social creatures who cannot live without communicating with each other. The use of speech is very influential on the speech partner, this can be seen from how the speech partner responds to the speaker. This study examines the performative speech acts of Gita Savitri Devi in the book Rentang Kisah which aims to describe the forms of performative speech acts in the book. This research use desciptive qualitative approach. The source of this research data comes from the speech of Gita Savitri in the book Rentang Kisah. The data collection technique used the free-of-conversation listening technique with the advanced technique of note-taking technique. Analysis of the data using the correlation method with the presentation of the results of the analysis using the informal method. The results showed that 82 performative utterances were classified into five, namely representative there were 44 data, directive had 8 data, expressive had 26 data, commissive had 1 data and declarative had 3 data.
\end{abstract}

Keywords: Performative speech acts, rentang kisah.

\section{PENDAHULUAN}

Tuturan atau ujaran adalah hal yang penting dalam berkomunikasi, dapat dilihat dalam banyak aspek kehidupan bahwa manusia tidak dapat hidup tanpa berkomunikasi satu sama lain. Penggunaan tuturan sangat berpengaruh pada mitra tutur, hal ini dapat dilihat dari bagaimana respon mitra tutur kepada penutur. Tindak tutur adalah tindakan-tindakan yang ditampilkan lewat tuturan, seperti permintaan maaf, keluhan, pujian, undangan, janji atau permohonan [1].

Tindak tutur atau ujaran adalah fenomena pragmatik yang tidak bisa terlepas dari konteks yang melingkupinya. Tuturan atau ujaran selain digunakan untuk menginformasikan sesuatu juga digunakan untuk mengekspresikan suatu tindakan tertentu [2].

Austin mengemukakan pandangannnya bahwa di dalam mengutarakan tuturan, seseorang dapat melakukan sesuatu selain mengatakan sesuatu [3] yang dijelaskan secara mudah yaitu ketika seseorang menggunakan kata-kata yang mengikat sesuatu, seperti berjanji, meminta maaf, menamakan dan menyatakan sesuatu, maka yang bersangkutan telah melakukan hal yang dikatakan tadi, hal ini dinamakan tuturan performatif. Tuturan performatif sangat berpengaruh jika diujarkan oleh seseorang yang memiliki kuasa dalam bidangnya, jika anda seorang mahasiswa dalam situasi ketika dosen anda memiliki kekuasaan besar atas nilai yang anda dapat, 
kemudian dosen anda menuturkan "Anda remidi" maka tuturan tersebut dapat memperlihatkan suatu tindakan untuk mengulang sebuah ujian yang harus anda lakukan.

Yule mengatakan tidak ada yang tahu jumlah kata kerja performatif dalam suatu bahasa, daripada mencoba mendaftar seluruh kata kerja performatif eksplisit yang mungkin ada, dan kemudian memilah-milahkannya, ada beberapa klasifikasi jenis tindak tutur umum yang biasanya digunakan oleh para peneliti yaitu, representatif, direktif, ekspresif, komisif dan deklaratif [4].

Representatif, yaitu tindak tutur yang mengikat penuturnya atas kebenaran apa yang dikatakannya. Dapat dicontohkan sebagai berikut:

Konteks : Seorang nasabah ingin membuka rekening baru di salah satu Bank.

Pegawai Bank
Nasabah

Pegawai Bank

Nasabah

Pegawai Bank

Nasabah
: "Ini KTP luar kota ya, pak?"

: "Iya, mbak. Saya asli Jogja, tapi sedang bertugas di Jakarta."

: "Oh, kerja di mana pak?"

: "Kejari. Kejaksaan Negeri, mbak."

: "Untuk jabatannya sendiri apa pak?"

: "Ajun Jaksa Madya."

Percakapan tersebut mempresentasikan bahwa nasabah mengakui dan menyatakan bahwa dirinya adalah orang Jogja asli yang sedang bertugas di Jakarta, dan bekerja di Kejaksaan Negeri sebagai Ajun Jaksa Madya.

Direktif, yaitu tindak tutur yang ditujukan agar lawan tutur melakukan tindakan yang dikehendaki, misalnya menyarankan, memerintah, memberikan aba-aba. Dapat dicontohkan sebagai berikut:

Konteks : Di suatu bank, seorang pegawai memanggil nasabah meminta untuk datang ke mejanya Pegawai Bank : "Antrian nomor tiga, silahkan."

(Seorang pria berdiri dari sofa ruang tunggu lalu berjalan menuju ke meja yang memanggilnya).

Kalimat "Antrian nomor tiga, silahkan" merupakan kalimat yang mengandung aba-aba sekaligus perintah bagi nasabah yang merasa dirinya mendapat antrian nomor tiga untuk segera menuju ke meja yang memanggil.

Ekspresif, yaitu tindak tutur yang ditujukan sebagai penilaian atau mengekspresikan terhadap hal yang dituturkan. Misalnya mengeluh. Dapat dicontohkan sebagai berikut:

Konteks : Seorang anak mengajak main ke rumah salah satu teman sekolahnya.

Yazid : "Mau main ke rumah iqbal tidak?"

Zidan : "Sepertimya tidak, aku capek, baru pulang."

Percakapan di atas mempresentasikan bahwa Zidan mengeluhkan atau mengekpresikan dirinya sedang merasa "capek" karena baru pulang dari suatu tempat.

Komisif, yaitu tindak tutur yang penuturnya harus melaksanakan apa yang telah dituturkan, seperti berjanji. Dapat dicontohkan sebagai berikut:

Konteks : Seseorang meminta temannya untuk datang ke acara pernikahan

Rani : "Ra ini dapet undangan dari Efi, nanti dateng ya reme-rame"

Rara : "Iya, pasti."

Rani : "Janji ya.."

Rara : "Iya aku janji bakal datang"

Percakapan di atas menunjukkan bahwa Rara menyanggupi undangan dari Rani karena dia sudah berjanji untuk datang ke pernikahan temannya.

Deklaratif/ isbati, yaitu tindak tutur yang dimaksudkan penuturnya untuk menciptakan hal yang baru. Seperti tuturan yang dimaksudkan memutuskan sesuatu. Dapat dicontohkan sebagai berikut:

Konteks : Seorang dosen di salah satu Universitas sedang mengadakan ulangan harian di kelas dan menentukan nilai yang harus dicapai.

Dosen : "Yang nilainya di bawah 70 nanti mengulang ya.."

Mahasiswa : "Baik bu." 
Kalimat di atas mempresentasikan bahwa dosen memiliki kuasa untuk memutuskan mahasiswa mengulang atau tidak pada ulangan harian tersebut, dengan adanya kalimat "Yang nilainya di bawah 70 nanti mengulang ya.." artinya secara otomatis mahasiswa yang mendapat nilai kurang dari 70 harus mengulang.

Realisasi sebuah tuturan bukan hanya dapat diujarkan, tuturan juga dapat disampaikan melalui sebuah tulisan seperti buku autobiografi. Autobiografi adalah sebuah buku yang ditulis oleh seseorang yang mengisahkan perjalanan pribadinya, termasuk kondisi psikologisnya serta ideologi yang dianutnya. Dalam buku autobiografi terdapat tuturan yang menyatakan, mengajak dan tuturan yang menunjukkan sebuah ekspresi. Biasanya dalam tuturan-tuturan tersebut terdapat ungkapan pesan atau ideologi penulis buku yang dapat diambil sebagai pelajaran.

Keadaan pandemi yang sedang dialami saat ini, terpaksa pemerintah harus mengurangi kegiatan di luar rumah, salah satunya pemerintah membuat keputusan untuk melakukan sekolah secara daring, Dalam situasi pandemi saat ini, banyak pelajar yang merasa bosan bahkan kehilangan semangat belajar karena harus belajar dari rumah. Penulis merasa perlu ada sesuatu yang dapat membangun semangat belajar siswa. Sebuah buku autobiografi Rentang Kisah yang ditulis oleh Gita Savitri Devi terdapat banyak sekali pelajaran-pelajaran yang dapat diambil untuk menyikapi kondisi pandemi seperti saat ini.

Maka dari itu, penulis mencoba untuk meneliti sebuah buku autobiografi Gita Savitri Devi, buku tersebut mengisahkan seorang perempuan yang merantau di Jerman untuk kuliah. Penulis berharap melalui buku Rentang Kisah ini peserta didik dapat mengambil banyak pelajaran dan dapat menerapkannya dikehidupan sehari-hari.

Penulis memilih buku karya Gita Savitri Devi dalam penelitian ini karena penulis rasa Gita Savitri Devi adalah salah satu figur yang cocok jika dikaitkan dengan pelajar. Gita adalah seorang influencer muda, content creator you tube, Gita juga sering membahas tentang pendidikan di chanel you tube nya, beliau juga seorang penulis yang salah satu bukunya sudah difilmkan yaitu Rentang Kisah. Gita melanjutkan studinya di Jerman dengan mengambil jurusan teknik kimia murni, yang menarik Gita mengaku bahwa dia merasa bukanlah anak yang pintar, bahkan Gita sendiri menyebut dirinya sebagai siswa yang malas belajar. Namun siapa sangka karena usahanya, Gita berhasil diterima di salah satu Universitas bergengsi di Berlin, Jerman.

Penulis memilih buku Rentang Kisah sebagai sumber penelitian karena dalam buku tersebut terdapat tindak tutur performatif yang dapat diambil dan diaplikasikan dalam pembelajaran bahasa Indonesia. Selain itu, penulis merasa tuturan performatif Gita Savitri Devi berhasil membuat penulis tertarik untuk membaca dan mengaplikasikannya dalam kehidupan sehari-hari. Dalam hal ini penulis menangkap bahwa tindak tutur performatif yang disampaikan Gita Savitri Devi dalam buku Rentang Kisah berhasil tersampaikan dengan baik kepada pembaca. Pada ungkapan tersebut, penulis mencoba untuk meneliti tindak tutur Gita Savitri Devi yang terdapat pada buku autobiografi Rentang Kisah.

Penelitian ini dapat diimplikasikan pada pembelajaran bahasa Indonesia pada kelas X semester genap di SMA dengan KD 3.14 Menilai hal yang dapat diteladani dari teks biografi serta 4.14 Mengungkapkan kembali hal-hal yang dapat diteladani dari tokoh yang terdapat dalam teks biografi yang dibaca secara tertulis. Metode pembelajaran yang dapat diterapkan dalam pembelajaran bahasa Indonesia adalah metode membaca, metode membaca bertujuan agar peserta didik memiliki kemampuan memahami teks bacaan yang diperlukan dalam belajar.

Pembelajaran bahasa Indonesia memiliki tujuan dapat meningkatkan keterampilan dan kemampuan siswa berkomunikasi menggunakan bahasa Indonesia yang baik dan benar serta melatih siswa menganalisis suatu masalah, sehingga siswa mampu mengidentifikasi materi yang diberikan guru. Proses tersebut bisa dinamakan interaksi edukatif yang sadar dengan tujuan yang akan dicapai. Staregi yang dapat digunakan adalah saintific learning, yaitu proses pembelajaran yang dirancang agar peserta didik aktif di dalam kelas. Teknik penyajian yang dapat dipakai dengan keterampilan membaca.

Ada beberapa tulisan bersangkutan dengan penelitian yang dilakukan oleh penulis. Penelitian tersebut menjadi referensi penulis ketika merumuskan masalah dalam meneliti tindak 
tutur performatif pada sebuah buku autobiografi karya Gita Savitri Devi yang berjudul Rentang Kisah.

Penelitian yang dilakukan oleh Fauzi (2015) dalam Jurnal Pustaka Budaya yang berjudul "Analisis Tindak Tutur Performatif dalam Film Musang Berjanggut Karya P. Ramlee". Tujuan penelitian tersebut adalah mendapatkan data berupa wujud penggambaran tindak tutur performatif dalam dialog film Musang Berjanggut karya P. Ramlee. Hasil dari penelitian tersebut penulis mendapatkan 15 data, dari 15 data tersebut diklasifikasikan atas 5 bentuk tindak tutur secara umum, yaitu representatif terdapat 4 data, direktif 2 data, ekspresif 2 data, komisif 2 data, dan deklaratif 5 data [5].

Persamaan penelitian ini dengan penelitian yang dilakukan oleh Fauzi adalah sama-sama meneliti tindak tutur performatif dan mengklasifikasikannya menjadi lima jenis tindak tutur secara umum dengan pendekatan deskriptif kualitatif dan hasil analisis disajikan dengan menggunakan kata-kata. Perbedaan penelitian ini dengan penelitian yang dilakukan oleh Fauzi terletak pada objeknya, objek penelitian ini adalah tuturan performatif Gita Savitri Devi dari buku autobiografi sedangkan penelitian yang dilakukan oleh Fauzi objeknya dari sebuah film.

Penelitian lain yang berkaitan dengan tindak tutur performatif dilakukan oleh Khoirunnisa (2018), dengan penelitian yang berjudul Analisis Tuturan Performatif dalam Pidato Shinzo Abe, dalam Jurnal Sasindo UNPAM. Tujuan dari penelitian tersebut adalah untuk mendeskripsikan tuturan performatif dalam teks pidato Sinzho Abe. Hasil analisis ditemukan 38 tuturan performatif, yaitu representatif, komisif dan direktif. Dalam penelitian ini tidak ditemukan tuturan performatif ekspresif yang digunakan untuk mengungkapkan rasa penyesalan dan minta maaf, serta tuturan performatif deklaratif yang berarti melarang atau memutuskan [6].

Persamaan penelitian ini dengan penelitian yang dilakukan oleh Khoirunnisa adalah sama-sama meneliti tindak tutur performatif dengan metode deskriptif kualitatif. Perbedaan penelitian ini dengan penelitian yang dilakukan oleh Khoirunnisa terletak pada objeknya, objek penelitian ini adalah tuturan performatif Gita Savitri Devi dari buku autobiografi sedangkan objek penelitian yang dilakukan oleh Khoirunnisa adalah teks pidato politik Shinzo Abe saat peresmian dirinya menjadi Menteri Jepang periode ketiga.

Penelitian selanjutnya dilakukan oleh Mujianto (2016) dari Universitas Muhammadiyah Malang yang berjudul Karakteristik Tuturan Performatif Guru dalam Pembelajaran Bahasa Indonesia Berdasarkan Pendekatan Saintifik dalam jurnal KEMBARA. Penelitian yang dilakukan bertujuan untuk menemukan kontruksi teoretis tuturan performatif guru dalam pembelajaran bahasa Indonesia berdasarkan pendekatan saintifik sebagai upaya mencapai suasana belajar yang aktif dan kondusif di SMA Muhammadiyah 2 Inovasi Kota Malang [7]. Ditemukan tindak tutur performatif berupa direktif, asertif, deklaratif, dan imperatif. Berdasarkan penelitian, guru lebih banyak menggunakan tuturan untuk menyatakan, memberi nilai, mengajarkan, mengemukakan pendapat dan memerintah. Dalam hal ini tuturan performatif digunakan untuk mengajarkan cara menjawab dan mengajukan pertanyaan dalam presentasi. Persamaannya yakni sama-sama meneliti tindak tutur performatif yang diklasifikasikan menjadi lima jenis tindak tutur secara umum. Perbedaannya dilihat dari objeknya, yakni objek penelitian ini adalah tuturan performatif Gita Savitri Devi dari buku autobiografi sedangkan objek penelitian yang dilakukan oleh Mujianto adalah tuturan performatif dari seorang guru bahasa Indonesia yang mengajar di SMP Muhammadiyah 2 Inovasi Kota Malang ketika pembelajaran sedang berlangsung di kelas.

Penelitian lain dilakukan oleh Christopher dkk (2016) dari Universitas Sydney Australia yang berjudul Deklaration, Accusiations And Judgment: Examining Conflict Of Interest Discourses As Performative Speech-Acts. (Deklarasi, Tuduhan, dan Penilaian: Menguji Wacana Konflik Kepentingan Sebagai Tindak Tutur Performatif). Tujuan penelitian tersebut untuk mengetahui tindak tutur performatif yang berfungsi untuk menyoroti pengaturan sosial dan peran otoritas dalam wacana Conflict Of Interest "konflik kepentingan" sehingga memberikan kerangka kerja yang kaya untuk memeriksa deklarasi dan tuduhan Conflict Of Interest "konflik kepentingan" yang sering muncul dalam konteks penelitian dan praktik biomedis [8]. 
Hasil dari penelitian tersebut menyimpulkan bahwa ada empat keuntungan dalam memahami wacana Conflict Of Interest sebagai tindak tutur performatif) yaitu: (1) Membahas efek deklarasi / tuduhan itu, (2) Menyoroti pengaturan sosial yang diperlukan untuk membuat pernyataan atau tuduhan; (3) Mengungkapkan peran pembicara yang berwenang dalam membuat deklarasi atau tuduhan Conflict Of Interest; dan (4) Penilaian tetap benar / salah atau baik / buruk terkait dengan deskriptif dan akun normative. Analisis performatif memungkinkan penggunaan akun yang fleksibel Gagasan Austin tentang tindak tutur yang tepat atau tidak patut. Persamaannya adalah sama-sama meneliti tindak tutur performatif. Perbedaannya terletak pada objek penelitiannya, yakni tuturan performatif dari wacana konflik.

Terakhir penelitian yang dilakukan oleh Al-Saedi dan Jabber (2020) dalam International Journal Of Linguistics, Literature And Translation (IJLLT) yang berjudul A Pragmatic Study Of Newspaper Headlines In Media Discourse: Iraq As A Case Study dari Universitas Misan, Sekolah Tinggi Pendidikan Dasar, Departemen Bahasa Inggris, Maysan, Irak. Tujuan penelitian tersebut untuk menyelidiki tindak tutur yang digunakan tajuk utama surat kabar Irak (Koran Alsabah) dan mengungkap cara tajuk berita yang meliput konflik Irak-ISIS di surat kabar lokal menggunakan makna pragmatis untuk membentuk perhatian pembaca [9].

Dalam menyampaikan pesan dibalik penggunaan headline surat kabar. Penelitian ini mencoba untuk menunjukan kata kerja performatif eksplisit dan implisit dari tindak tutur performatif berita utama, dari penelitian tersebut mengungkapkan bahwa ekspresif dan deklaratif adalah tindak tutur yang paling menonjol dan umum digunakan untuk judul berita utama. Hasil analisis data menunjukan semua kategori tindak tutur ini digunakan secara eksplisit dan implisit. Ringaksnya, penggunaan tindak tutur tersebut menjadi headline Koran Alsabah menyikapi perasaan pembaca untuk mengungkapkan pencapaian kemenangan dan pembebasan. Persamaannya adalah sama-sama meneliti tentang tindak tutur performatif. Perbedaannya terletak pada objek kajiannya, yakni tuturan performatif dari tajuk utama koran Al-Sabah Misan Irak.

Dari paparan di atas, dapat disimpulkan penelitian ini dengan penelitian sebelumnya memiliki persamaan dan perbedaan, yakni sama-sama mengkaji tindak tutur performatif dan mengklasifikasikannya menjadi lima jenis tindak tutur secara umum. Sedangkan perbedaannya terletak pada objek kajian. Penelitian pertama dari film, penelitian kedua dari teks pidato, penelitian ketiga dari tuturan guru ketika pembelajaran berlangsung, penelitian keempat dari wacana konflik, penelitian kelima dari tajuk utama surat kabar. Kebaruan dari penelitian ini adalah meneliti tindak tutur pada sebuah buku autobigrafi yang bisa diterapkan pada pembelajaran bahasa Indonesia.

Berdasarkan semua permasalahan yang telah dipaparkan di atas, penulis memilih tuturan Gita Savitri Devi dalam buku Rentang Kisah untuk diteliti tindak tutur performatifnya yang akan diklasifikasikan menjadi lima jenis tindak tutur menurut Searle. Maka dari itu perlu adanya penelitian tentang penggunaan tindak tutur performatif dengan judul "Tindak Tutur Performatif Pada Buku Autobiografi Rentang Kisah karya Gita Savitri Devi”. Tujuan penelitian ini untuk mendeskripsikan tindak tutur performatif Gita Savitri Devi dalam buku Rentang Kisah.

\section{METODOLOGI PENELITIAN}

Pendekatan penelitian ini menggunakan pendekatan deskriptif kualitatif. Pendekatan deskriptif merupakan penelitian yang hasil laporannya berupa petikan data yang digunakan sebagai gambaran penyajian. Sedangkan metode kualitatif adalah data yang dikumpulkan berupa kata-kata dan gambar [10]. Berdasarkan penjabaran mengenai pendekatan deskriptif kualitatif tersebut penulis berusaha memahami dan mendeskripsikan hasil penelitian disajikan dalam bentuk teks tertulis yang dihasilkan dari proses simak tanpa libat cakap.

Sumber data dalam penelitian ini adalah buku Rentang Kisah karya Gita Savitri Devi, berisi 207 halaman yang diterbitkan oleh Gagas Media pada tahun 2017 di Jakarta. Wujud data penelitian ini berupa penggalan tuturan Gita Savitri Devi yang diduga mengandung tuturan performatif dalam buku Rentang Kisah. 
Berdasarkan sumber data dan wujud data yang sudah ditentukan, maka data tuturan antar tokoh dalam buku tersebut diidentifikasikan berdasarkan bentuk tindak tutur secara umum menurut Searle, yaitu tindak tutur representatif, direktif, ekspresif, komisif dan deklaratif, kemudian data diklasifikasikan berdasarkan lima bentuk tindak tutur tersebut.

Teknik pengumpulan data yang digunakan dalam penelitian ini adalah metode simak. Metode simak adalah metode pengumpulan data yang dilakukan dengan cara menyimak mendengarkan. Metode ini memiliki teknik lanjutan, yaitu teknik simak bebas libat cakap. Teknik simak bebas libat cakap dilakukan dengan menyimak pengguna bahasa tanpa terlibat dalam percakapan [11]. Artinya penulis tidak terlibat percakapan secara langsung dengan Gita Savitri Devi, melainkan hanya membaca buku Rentang Kisah disertai dengan mencatat. mencatat kalimat-kalimat yang diduga mengandung tuturan performatif.

Teknik analisis data penelitian ini menggunakan metode korelasi. Metode korelasi atau metode pemadanan adalah metode analisis yang menjelaskan objek kajian dengan menghubungkan sesuatu yang lain, termasuk dengan mengkorelasikan konteks situasi. [12]. Hasil analisis data disajikan dengan menggunakan teknik informal, yakni data yang disajikan dalam bentuk ungkapan bahasa berupa kata-kata yang mudah dipahami. Penyajian analisisnya dengan menggambarkan dalam bentuk tulisan.

\section{HASIL DAN PEMBAHASAN}

\section{Hasil Penelitian}

\section{Tindak Tutur Performatif Pada Buku Autobiografi Rentang Kisah Karya Gita Savitri Devi}

Hasil penelitian menunjukan terdapat 82 tuturan performatif yang diklasifikasikan menjadi lima, yaitu representatif terdapat 44 data, direktif terdapat 8 data, ekspresif terdapat 26 data, komisif terdapat 1 data dan deklaratif terdapat 3 data. Berikut pembahasannya:

\section{Tindak Tutur Representatif}

Tindak tutur representatif yaitu tindak tutur yang mengikat penuturnya atas kebenaran apa yang dikatakannya.

Konteks : Gita dan ibunya sedang duduk di sofa, Gita ingin memberitahu ibunya tentang keadaan yang dirasakan.

Gita : "Ma, Gita sakit. Lemes banget nggak tahu kenapa. Di leher Gita ada benjolan, tapi nggak sakit, sih, kalau ditekan," jelasku sambil memegang leher sebelah kiri.

Mama : "Benjolan apaan?" (halaman 7).

Tuturan di atas menunjukkan tuturan representatif, yang terdapat pada kalimat "Ma, Gita sakit". Data di atas merupakan tindak tutur representatif memberitahukan, karena kalimat "Ma, Gita sakit" menunjukkan kalimat informatif yang bertujuan untuk memberitahukan informasi kepada ibunya bahwa dia sakit, dibuktikan dengan ada benjolan di leher yang jika ditekan tidak terasa sakit.

\section{Tindak Tutur Direktif}

Tindak tutur direktif yaitu ditujukan agar lawan tutur melakukakan tindakan seperti yang diperintah oleh penutur.

Konteks : Latar tempat terjadinya peristiwa ini di rumah. Saat itu Gita sedang bercerita kepada ibunya kalau di lehernya terdapat benjolan besar. Ibunya panik dan dia langsung menelepon adiknya yang merupakan seorang dokter.

Ibu : :Mi, biso ke rumah, dak? Di lehernyo Gita ada benjolan besak. Tolong diperikso pacak!" jelas ibu pakai bahasa Palembang. (halaman 8). 
Tuturan di atas menunjukkan tuturan direktif. Bentuk tuturan direktif terdapat pada kalimat "Tolong diperikso pacak!". Kalimat tersebut menunjukkan tuturan direktif memerintah, karena terdapat kata 'tolong' yang bermaksud untuk memerintah melakukan sesuatu.

\section{Tidak Tutur Ekspresif}

Tindak tutur ekspresif yaitu tindak tutur yang ditujukan sebagai penilaian terhadap hal yang dituturkan.

Konteks : Latar tempat terjadinya peristiwa ini di Jerman. Saat itu Gita hidup di Jerman sebagai minoritas.

Gita : Nyatanya perlakuan tidak enak itu hanyalah segelintir. Kebanyakan "bule" ternyata baik, biasa aja kalau lihat orang pakai kerudung, dan biasa aja kalau lihat orang salat ataupun puasa. (halaman 170).

Tuturan di atas menunjukkan tuturan ekspresif, yang terdapat pada kalimat "Kebanyakan 'bule' ternyata baik". Kalimat tersebut merupakan tuturan ekspresif memuji, karena terdapat kata 'baik' yang digunakan untuk memuji. Pada kalimat tersebut terlihat Gita memuji orang luar negeri karena bersikap baik terhadap minoritas, mereka bersikap biasa ketika melihat orang muslim pakai kerudung, salat ataupun puasa.

\section{Tindak Tutur Komisif}

Tindak tutur komisif adalah tindak tutur yang penuturnya harus melaksanakan apa yang telah dituturkan.

Konteks : Latar tempat terjadinya peristiwa ini di Jakarta. Saat itu Gita sudah memutuskan berhijab, banyak orang yang bertanya pada Gita "Apa tidak takut berhijab di Jerman?".

Gita : Percaya atau nggak, nggak ada sedikit pun perasaan takut. Seandainya ada hal-hal yang nggak mengenakan terjadi, aku melihat itu sebagai jihad, sebagai perjuangan. Seandainya aku didiskriminasi karena kerudung dan aku bisa melewati itu, itu adalah caraku mempertahankan prinsip agama dan memperjuangkan kepercayaan. (halaman.130-131).

Tuturan di atas menunjukkan tuturan komisif, yang terdapat pada kalimat "Seandainya ada hal-hal yang nggak mengenakan terjadi, aku melihat itu sebagai jihad". Kalimat tersebut menunjukkan tindak tutur komisif menyatakan kesanggupan, dilihat dari kesanggupan Gita setelah memutuskan untuk mulai memakai kerudung. Dia menegaskan akan menerima semua konsekuensi yang akan diterimanya jika sesuatu yang tidak mengenakan terjadi dalam hidupnya suatu hari nanti. Kalimat yang menyatakan kesanggupan itu mengikat seorang penuturnya, maka data ini masuk pada tindak tutur komisif.

\section{Tindak Tutur Deklaratif}

Tindak tutur deklaratif/ isbati, yaitu tindak tutur yang ditujukan penuturnya untuk membuat hal yang baru.

Konteks : Setelah Gita dinyatakan lulus ujian saringan masuk ITB, ibunya Gita malah memberi pilihan lain, beliau menawarkan mau kuliah di ITB atau Jerman.

Gita : Setelah berpikir panjang, akhirnya dengan berat hati aku harus say goodbye sama ITB, kampus impian. Aku memilih melanjutkan studi di Jerman. (halaman 36).

Tuturan di atas menunjukkan tuturan deklaratif, yang terdapat pada kalimat "Akhirnya dengan berat hati aku harus say goodbye sama ITB, kampus impian. Aku memilih melanjutkan studi di Jerman”. Kalimat tersebut menunjukkan tuturan ekspresif 
memutuskan, karena mengandung kalimat deklaratif dengan menciptakan hal yang baru, yaitu Gita memilih melanjutkan kuliah di Jerman.

\section{Pembahasan}

Penelitian yang dilakukan ini membahas tentang tindak tutur performatif yang secara umum diklasifikasikan menjadi lima yaitu representatif, direktif, komisif, ekspresif dan deklaratif. Penelitian ini dapat dijadikan sebagai bahan ajar yang dapat digunakan oleh pendidik dalam kegiatan pembelajaran. Hasil analisis tuturan Gita Savitri Devi dapat dijadikan tambahan bahan ajar untuk pembelajaran teks biografi pada semester genap kelas X SMA kurikulum 2013 revisi 2020 dalam KD 3.14 Menilai hal yang dapat diteladani dari teks biografi serta 4.14 Mengungkapkan kembali hal-hal yang dapat diteladani dari tokoh yang terdapat dalam teks biografi yang dibaca secara tertulis. Diharapkan peserta didik dapat meneladani nilai-nilai yang terkandung dalam buku autobiografi Rentang Kisah sebagai motivasi belajar siswa di masa pandemi. Dengan menampilkan biografi seorang konten video You Tube yang berhasil diterima di salah satu Universitas bergengsi di Jerman. Diharapkan peserta didik tidak asing dengan tokoh tersebut dan memiliki semangat untuk terus belajar.

Adapun langkah-langkah pembelajarannya meliputi sebagai berikut.

1. Kegiatan pendahuluan

a) Peserta didik mengucapkan salam, berdoa, dan mengondisikan diri siap belajar dengan sungguh-sungguh.

b) Guru melakukan presensi kehadiran peserta didik.

c) Guru bertanya jawab tentang buku autobiografi.

d) Guru membuka kelas dengan hal-hal yang dapat membuat siswa semangat mempelajari teks biografi dan ada hubungannya dengan materi yang akan disampaikan pada hari ini.

e) Guru menyampaikan tujuan pembelajaran yang ingin dicapai pada KD 3.14 dan 4.14 .

f) Guru menyampaikan langkah-langkah pembelajaran yang akan dilakukan.

2. Kegiatan Inti

(Pertemuan Pertama)

a) Peserta didik berkelompok, masing-masing kelompok terdiri dari empat orang.

b) Peserta didik secara berkelompok membaca cerita biografi yang telah disajikan oleh guru baik secara lisan maupun tulisan.

c) Peserta didik secara berkelompok mampu mengidentifikasi peristiwa seperti perjalanan pendidikan, karier, perjuangan dalam biografi tokoh yang dibaca maupun yang didengar.

d) Peserta didik secara berkelompok mampu menyampaikan kembali hal-hal yang dapat diteladani dari peristiwa yang tertuang dalam teks biografi yang dibaca maupun yang didengar.

e) Peserta didik bertanya tentang teks biogrofi yang dibaca maupun yang didengar.

f) Peserta didik memverivikasi ketepatan hasil kerja kelompok melalui kegiatan presentasi hasil kelompok dam tanya jawab antar kelompok.

g) Peserta didik yang lain menyimak, menanggapi, mengajukan pertanyaan atau memberi saran terkait dengan hasil diskusi kelompok yang dipresentasikan.

(Pertemuan Kedua)

a) Peserta didik membaca buku siswa pada materi teks biografi. 
b) Peserta didik diminta untuk mencari tokoh Indonesia dan menceritakan biografi tokoh tersebut.

c) Peserta didik menuliskan biografi tokoh Indonesia dan meneledani nilai-nilai yang terdapat dalam cerita tersebut.

d) Peserta didik mempresentasikan hasil tulisannya di depan kelas.

e) Peserta didik lain memperhatikan temannya yang sedang presentasi dengan seksama.

f) Peserta didik menanggapi secara lisan atau tulis terhadap hasil tugas teman atau kelompok lain.

3. Penutup

a) Peserta didik menyimpulkan materi terkait dengan teks biografi baik secara lisan maupun tulisan.

b) Peserta didik merefleksi penguasaan materi yang telah dipelajari dengan membuat catatan penguasaan materi dengan teliti dan bertanggung jawab.

c) Peserta didik saling memberikan umpan balik dan hasil evaluasi pembelajaran yang telah dicapai dengan teliti dan bertanggung jawab.

d) Guru mengucapkan salam penutup tanda bahwa pembelajaran telah selesai.

\section{SIMPULAN}

Berdasarkan penelitian yang sudah dilakukan ditemukan 82 tuturan performatif yang terdapat dalam buku autobiografi Rentang Kisah karya Gita Savitri Devi. Terdapat 44 data representatif, terdiri dari tindak tutur memberitahukan ada 4 data, menyatakan ada 37 data, dan menyebutkan ada 3 data. Terdapat 8 data direktif, terdiri dari tindak tutur meminta ada 1 data, memerintah ada 4 data, menyarankan ada 2 data dan mengajak ada 1 data. Terdapat 26 data tindak tutur ekspresif, terdiri dari memuji 1 data, mengkritik 1 data, marah 4 data, merasa heran 1 data, pasrah 1 data, gembira 2 data, takut 4 data, khawatir 3 data, mengucapkan terima kasih 2 data, menyesal 2 data, ragu 1 data, merasa tenang 2 data, dan mengeluh 2 data.

Terdapat 1 data tindak tutur komisif, berupa data yang menyatakan kesanggupan dan terdapat 3 data tindak tutur deklaratif, terdiri dari 2 data tindak tutur deklaratif memutuskan dan 1 tindak tutur deklaratif mengesahkan. Data paling banyak ditemukan pada tindak tutur representatif, hal tersebut disebabkan karena buku autobiografi banyak menggunakan kata-kata yang mengandung pernyataan pengarang. Hasil penelitian dapat diimplikasikan pada pembelajaran bahasa Indonesia di SMA kelas X, semester genap, kurikulum 2013 revisi 2020 dalam KD 3.14 Menilai hal yang dapat diteladani dari teks biografi serta 4.14 Mengungkapkan kembali hal-hal yang dapat diteladani dari tokoh yang terdapat dalam teks biografi yang dibaca secara tertulis.

\section{REFERENCES}

[1] Yule, George. 2006. Pragmatik. Yogyakarta: Pustaka Pelajar.

[2] Cummings, Louise. 2007. Pragmatik Sebuah Perspektif Multidisipliner. Yogyakarta: pustaka belajar.

[3] Wijana, I Dewa Putu. 1996. Dasar-Dasar Pragmatik. Yogyakarta: ANDI.

[4] Yule, George. 2006. Pragmatik. Yogyakarta: Pustaka Pelajar.

[5] Fauzi, M. (2015). Analisis Tindak Tutur Performatif Dalam Film Musang Berjanggut Karya P. Ramlee. Jurnal Pustaka Budaya, 2 (2), 127027.

[6] Khoirunnisa, E. M. (2018). Analisis Tuturan Performatif Dalam Pidato Sinzho Abe. Jurnal sasindo UNPAM, 6 (1), 76-95. 
[7] Mujianto, G. (2017). Karakteristik Tuturan Performatif Guru Dalam Pembelajaran Bahasa Indonesia Berdasarkan Pendekatan Saintifik. KEMBARA Journal Of Scientific Language Literature And Teaching, 2 (2), 172-186.

[8] Mayes C,. Lipworth, W,. \& Kerridge, I. (2016). Declarations, Accusations And Judgement: Examining Conflict Of Interest Discourses As Performative Speech-Acts. Medicine, Healthcare and Philosophy, 19 (3), 455-462.

[9] Alsaedi, Hayder Tuama Jasim, dan Khalid Wahaab Jabber. "A Pragmatic Study Of Newspaper Headlines In Media Discourse: Iraq As A Case Study”. International Journal Of Linguistics, Literature and Translation 3.3 (2020): 48-59.

[10] Moleong, Lexy J. 2019. Metodelogi Penelitian Kualitatif (Edisi Revisi). Bandung: Remaja Rosdakarya.

[11] Alifudin Dan Beni Ahmad Saebani. 2009. Metodologi Penelitian Kualitatif. Bandung: Pustaka Setia.

[12] Hermaji, Bowo. 2016. Teori dan Metode Sosiolinguistik. Yogyakarta: magnum pustaka utama. 